\author{
Marcin Piotr Puczyński \\ WYdZIAŁ HistORYCZNO-SOCJOLOGICZNY \\ UNIWERSYTET W BIAŁYMSTOKU \\ E-MAIL: MPUCZYNSKI87@GMAIL.COM
}

\title{
IDEA SPOŁECZEŃSTWA NARODOWEGO FLORIANA ZNANIECKIEGO W WARUNKACH DEMOKRATYCZNYCH NA PRZYKŁADZIE III RZECZYPOSPOLITEJ POLSKIEJ
}

\section{Wstęp}

We współczesnej literaturze socjologicznej społeczeństwo określa się jako zbiorowość powiązanych ze sobą w „przestrzeni międzyludzkiej” jednostek, która nieustannie się zmienia, przekształca, „żyje”. Wzory, reguły, normy, wartości, które kierują ludzkimi działaniami, decydują o ich indywidualnej tożsamości, określają ich uczestnictwo w grupach, wyznaczają relacje z innymi ludźmi [Sztompka 2007: 31]. Florian Znaniecki społeczeństwem nazywa ściśle powiązany kompleks grup społecznych, ogniskujący się we wspólnym podporządkowaniu wszystkich jednej, najbardziej wpływowej grupie [za: Znaniecki 1973: 65].

W literaturze socjologicznej naród najczęściej jest opisywany jako wspólnota ludzi powstała w toku rozwoju historycznego, mająca nazwę własną przyjętą przez członków wspólnoty lub nadaną jej przez innych, język ojczysty, terytorium (ojczyznę), które zamieszkuje przynajmniej część narodu, wspólne pochodzenie lub przekonanie o wspólnym pochodzeniu, wspólna historię i kulturę, z którą część zbiorowości się identyfikuje, wspólne państwo lub dążenie do posiadania własnej organizacji politycznej, poczucie więzi emocjonalnej i solidarności między członkami wspólnoty oraz przeświadczenie o jej specyficznych wartościach [Budyta-Budzyńska 2010: 55]. W socjologicznym podejściu do badania społeczności narodowych wyodrębniły się trzy koncepcje. Są to:

- koncepcja naturalistyczna - naród traktowany jest jako grupa genetyczna, przekazująca swe właściwości psychofizyczne następnym generacjom;

- koncepcja politologiczna - naród jest utożsamiany z państwem, jest wspólnotą polityczną; 
- koncepcja kulturowa - naród jest wspólnotą kultury, członkowie narodu uczestniczą w kulturze narodowej, obejmującej język, sztukę, obyczaje, naukę [Szacki 1990: 14-15].

Florian Znaniecki - przedstawiciel humanistycznej socjologii - w swych pracach stał na stanowisku, iż naród jest fenomenem kulturowym. Takie postawienie sprawy oznaczało, że występuje przeciwko koncepcjom naturalistycznym i politologicznym. W ujęciu Znanieckiego naród jest wytworem cywilizacji, grupą kulturową, zorganizowaną na zasadzie przodownictwa. Jako wspólnota duchowa może istnieć niezależnie od terytorium i organizacji państwowej, jest historycznie zmienny, o jego istnieniu stanowi kultura, która obejmuje całą twórczość danego narodu. Kultura narodowa, obyczaj, kult religijny, światopogląd, ideały narodowe, tradycja historyczna są wspólnymi wartościami grupy narodowej i są potencjalnie dostępne dla wszystkich członków grupy. „Zasadą odrębności" narodu - jako grupy kulturowej jest wspólna kultura. Naród - pisał Znaniecki [1990: 3-4] - to „solidarna zbiorowość, złożona z setek tysięcy czy milionów ludzi uczestniczących w tej samej kulturze, może istnieć przez dłuższy czas bez wspólnej władzy politycznej”. W warunkach demokratycznych w III Rzeczypospolitej Polskiej (RP) zostały stworzone warunki do funkcjonowania i rozwoju różnych typów społeczeństw opartych o kryteria tożsamościowe. Zgodnie $\mathrm{z}$ intencją F. Znanieckiego grupy narodowe i etniczne mogą rozwijać kulturę narodową, wspólne realizować ideały kulturowe, angażować się w prace na rzecz dobra wspólnego. Niemniejszy artykuł jest próbą odpowiedzi na pytanie: W jakim stopniu idee społeczeństwa narodowego F. Znanieckiego są aktualne w III RP? Opierając się na literaturze przedmiotu przedstawiono idee społeczeństwa narodowego F. Znanieckiego oraz wybrane instytucje i organizacje narodowe działające w III Rzeczypospolitej Polskiej.

\section{Idea społeczeństwa narodowego według Floriana Znanieckiego}

Społeczeństwo Florian Znaniecki określa jako kompleks grup społecznych podporządkowanych jednej, najbardziej wpływowej grupie. Do ukształtowania się grupy - zdaniem socjologa - są niezbędne więzi, które łączą członków grup, ich wspólne doświadczenia i działania oraz wspólny system wartości: język, idee, wierzenia, tradycja kulturalna, interesy ekonomiczne, cele. Korelatem grupy społecznej zawsze jest jej system kulturowy. Przynależność do danej grupy społecznej decyduje o tym, w jakich systemach kulturalnych - technicznych, 
religijnych, poznawczych, estetycznych - jednostka będzie uczestniczyła. Przekaz kulturowy wpływa na trwałość grup społecznych, ich rozwój, przekształcanie lub powstawanie w nowej postaci [za: Znaniecki 1973: 132]. Według Znanieckiego, naród i państwo to dwie najbardziej zaawansowane grupy podstawowe, dominujące, „konkretne”. W ocenie socjologa, naród jest jednością kultury, solidarności i organizacji społecznej [Znaniecki 1990: 33-34]. To grupa kulturowa, zorganizowana na zasadzie przewodnictwa, oparta na wspólności kultury duchowej. Jako wspólnota duchowa może istnieć niezależnie od terytorium i organizacji państwowej [za: Znaniecki 1990: 3-4; Zwoliński 2005: 135], jest historycznie zmienny, o jego istnieniu stanowi kultura [za: Znaniecki 1990: 33-34; Kłosowska 2005: 51], która obejmuje całą twórczość danego narodu, wszystkie wytwory materialno-techniczne, intelektualne, artystyczne, estetyczne, język, druk, pismo oraz inne symbole jako środki komunikowania, wszelkie wzory zachowań i działań, wartości i ideały (wolność, sprawiedliwość, honor) i normy z nich wynikające. Kultura narodowa, obyczaj, kult religijny, światopogląd, ideały narodowe, tradycja historyczna są wspólnymi wartościami grupy narodowej i są potencjalnie dostępne dla wszystkich członków grupy. „Zasadą odrębności” narodu - jako grupy kulturowej jest wspólna, względnie swoista kultura. Członkowie narodu dbają o zachowanie własnego wzoru kulturowego oraz świadomie dążą do uczestnictwa w utrzymaniu i rozwoju wspólnego zasobu kultury, niemniej swoje wartości traktują jako nadrzędne w stosunku do wartości innych narodów [Znaniecki 1973: 396]. Zdaniem Znanieckiego [1973: 229-230] wartości, ideały narodu mogą być podstawą solidarności społecznej lub źródłem konfliktów z członkami innych kultur narodowych. Jednak w momentach krytycznych solidarność narodowa bierze górę nad wszelkimi innymi rodzajami solidarności.

Z teorii grup społecznych wyrosła teoria społeczeństwa. Znaniecki proponował zastąpienie terminu społeczeństwo przez określenia: „społeczeństwo narodowe”, „społeczeństwo państwowe”. „Rozmaite typy grup społecznych - pisał Znaniecki - (...) w ciągu dziejów dążyły do tego, by stać się konkretnymi społeczeństwami, zadawalającymi wszystkie dążenia i zainteresowania swoich członków. (...) Dziś trzy grupy zdążają w tym kierunku - naród, państwo i klasa robotnicza" [Znaniecki 1973: 370]. Według Znanieckiego, społeczeństwa współczesne to społeczeństwa narodowe, państwowe lub klasowe. Wszystkie nowoczesne społeczeństwa o kulturach narodowych - podkreśla socjolog dążą do rozwoju i ekspansji, ciągle ewoluują, zmieniają się, stają [Znaniecki 1990: 165-205]. Tylko twórcze rozwijanie własnej kultury narodowej i postaw czynnego współdziałania w sferze kultury, gospodarki, polityki zapewnia rozwój społeczeństw narodowych i jest jedynym sposobem przeciwdziałania 
konfliktom między społeczeństwami o kulturach narodowych [Znaniecki 1990: 206-249]. Realność każdego społeczeństwa narodowego jako zbiorowości społecznej, wyraża się w wytworzeniu własnej organizacji społecznej w postaci instytucji przodownictwa sprawowanego przez twórców kultury, instytucji zachowujących dorobek i dziedzictwo kulturalne narodu, tworzących, upowszechniających treści kulturowe wśród członków społeczeństwa oraz instytucji odrębnych od instytucji państwowych jako instytucji społeczności politycznej o innych funkcjach i typie władztwa [Turowski 1999: 276-277]. Dla F. Znanieckiego [1990: 122-124] społeczeństwa narodowe są konstruktem świadomościowym tworzonym przez pewne odłamy elit (intelektualistów, artystów, nauczycieli i księży). Cechą charakterystyczną społeczeństw narodowych jest otwartość, pluralizm i prozelityzm.

\section{Mniejszości narodowe w III Rzeczypospolitej Polskiej. Ochrona mniejszości w prawie państwowym}

Państwo polskie przez całą swą historię było znacznie zróżnicowane pod względem narodowo-etnicznym. Po II wojnie światowej sytuacja uległa radykalnej zmianie. W wyniku zmian granic, przesiedleń ludności i prowadzonej polityce asymilacyjnej wobec mniejszości, Polska w okresie PRL-u stała się państwem niemal jednolitym pod względem narodowo-etnicznym. Tak też była odbierana w powszechnej świadomości. Po 1989 roku członkowie poszczególnych grup narodowych zaczęli otwarcie mówić o swej kulturowej odmienności i starać się o uzyskanie praw, jakie przysługują mniejszościom w wielu państwach demokracji zachodnich. Społeczeństwo polskie zaczęło sobie uświadamiać własną kulturową różnorodność, co potwierdzają wyniki Spisu Powszechnego z 2002 i 2011 roku.

Wyniki Narodowego Spisu Powszechnego z 2002 roku wykazały, iż około $4 \%$ osób zadeklarowało inne poczucie przynależności kulturowej niż polskie - 1,23\% (471,5 tys. osób) - przynależność do innej narodowości, a 2,03\% ludności $(774,9$ tys. osób) nie określiło swej narodowości. Ponad 96\% ludności zadeklarowało narodowość polską. Zgodnie z danymi spisu w Polsce żyje około 800 tys. przedstawicieli 9 mniejszości narodowych i 4 etnicznych - m.in.: Niemcy (około 150 tys. - 0,4\%), Białorusini (około 50 tys.), Ukraińcy (ponad 30 tys.), Litwini, Słowacy, Czesi, Rosjanie, Ormianie, Żydzi, Grecy, Wietnamczycy oraz mniejszości etniczne: Tatarzy, Romowie [Narodowy Spis... 2002]. $\mathrm{Z}$ punktu widzenia rozmieszczenia terytorialnego ludność o tożsamości nie- 
polskiej (471,5 tys.) koncentruje się głównie w trzech województwach: śląskim - 186,3 tys. (39,5\%), opolskim - 133,3 tys. $(28,3 \%)$ i podlaskim - 55, 2 tys. $(11,7 \%)$. Udział w ogólnej liczbie ludności kształtuje się następująco: w województwie opolskim - 12,5\%, w podlaskim - 4,6\% i śląskim - 3,9\% [Narodowy Spis... 2002]. Większość mniejszości narodowych zamieszkuje zwarcie pewne terytoria: Litwini zamieszkują rejon przygraniczny koło Puńska, Białorusini południowo-wschodnią część województwa podlaskiego, Ukraińcy - północną część województwa warmińsko-mazurskiego, południową część województwa pomorskiego oraz województwa dolnośląskie i podkarpackie, Słowacy - rejony przygraniczne na Spiszu i Orawie, Niemcy - obszar na wschód od Opola, Żydzi - duże ośrodki miejskie, Czesi - okolice Głubczyc, Kudawy i Wałbrzycha, Rosjanie i Tatarzy - północno-wschodnią część województwa podlaskiego [Siegień-Matyjewicz 2007: 23].

Wyniki kolejnego spisu powszechnego - Narodowego Spisu Powszechnego Ludności i Mieszkań z 2011 roku wskazują na wzrost poczucia odrębności etnicznej społeczności regionalnych w Polsce, choć w większości przypadków wiąże się to z jednoczesnym odczuwaniem polskiej tożsamości narodowej. Do najliczniejszych innych niż polskie identyfikacji narodowo-etnicznych należy zaliczyć deklaracje śląskie - 809 tys., kaszubskie - 228 tys. oraz niemieckie 109 tys., ukraińskie - 48 tys., białoruskie - 47 tys., romskie - 16 tys., rosyjskie - 13 tys., amerykańskie - 11 tys., łemkowskie - 10 tys. [Wyniki Narodowego Spisu... 2011: 18]. W spisie ludności w 2011 roku umożliwiono mieszkańcom Polski wyrażanie złożonych tożsamości narodowo-etnicznych, poprzez zadanie osobom spisywanym dwóch pytań o przynależność narodowo-etniczną. Z możliwości wyrażenia podwójnych tożsamości etnicznych skorzystało 871 tys. osób. Na podstawie uzyskanych wyników można stwierdzić, że wśród mieszkańców Polski dominuje ludność o jednorodnej polskiej tożsamości narodowej obejmująca 35251 tys. co stanowi 91,6\%. Około 834 tys. (2,17\%) osób posiada zarówno polską jak i inną niż polska tożsamość narodowo-etniczną. Deklarujący wyłącznie niepolską przynależność narodową lub etniczną stanowią grupę liczącą 554 tys.(1,44\%) osób, z czego 38 tys. - to identyfikujący się z dwiema niepolskimi narodowościami [Wyniki Narodowego Spisu... 2011: 17-18]. Wyniki Spisu Powszechnego z 2011 roku odnoszącego się do mniejszości narodowych i etnicznych stały się przedmiotem krytyki wielu środowisk społecznych, które uważają, że spis nie odzwierciedla rzeczywistego stanu narodowego w Polsce. Wielu bowiem przedstawicieli mniejszości, pytanych o narodowość, religię często wstydzi się do niej przyznać. W Polsce jest to dobrze widoczne w przypadku Białorusinów, Ukraińców, Żydów [Bołtryk 2012]. 
Transformacja ustrojowa Polski stała się istotnym czynnikiem determinującym zmianę położenia mniejszości narodowych i etnicznych, jednak nie dawała warunków do tworzenia się narodu. Władze demokratyczne od 1989 roku prowadziły jedynie nową politykę wobec mniejszości narodowych, politykę otwartości wobec ich potrzeb oraz uznania przedstawicieli mniejszości za równoprawnych obywateli państwa polskiego. Celem polityki po 1989 roku stało się określenie nienaruszalnego standardu, gwarantującego każdej grupie narodowej i etnicznej możliwości rozwoju, kultywowania odrębności, pielęgnowania i rozwijania języka, kultury i tradycji. Przyjęto, że deklaracja o uczestnictwie w życiu danej społeczności wynikać powinna z indywidualnej opcji, a więc subiektywnego rozstrzygnięcia o swej przynależności narodowej. Podstawą relacji między państwem polskim i jego organami a przedstawicielami mniejszości stały się postanowienia prawa międzynarodowego („Deklaracja praw należących do mniejszości narodowych lub etnicznych” przyjęta przez Zgromadzenie Narodowe ONZ, Konwencja Ramowa Rady Europy o Ochronie Mniejszości Narodowych), [Łoziński 1996: 8-9] i wewnętrznego (ustawa o mniejszościach narodowych i etnicznych oraz o języku regionalnym [2005], Konstytucja RP z 1997 roku) oraz zasada lojalności wobec państwa [Michalik, Chałupczak 2006: 73-78]. Poziom i jakość społecznego funkcjonowania mniejszości narodowych zostały ściśle powiązane $\mathrm{z}$ modelem państwa, w którym konstytucyjne rządy są zobowiązane do zapewnienia wszystkim obywatelom podstawowych równości, w tym równości wobec prawa, swobodnego dostępu do wykształcenia, możliwości nauki i nauczania w językach ojczystych, wolności wyznania, równego udziału w życiu politycznym i gospodarczym. Ochroną praw mniejszości narodowych od 1989 roku zajmują się instytucje państwowe: sejmowa Komisja Mniejszości Narodowych i Etnicznych, Ministerstwo Spraw Wewnętrznych i Administracji, Ministerstwo Edukacji Narodowej, Ministerstwo Kultury i Dziedzictwa Narodowego, Ministerstwo Spraw Zagranicznych, Ministerstwo Sprawiedliwości, Główny Urząd Statystyczny, Rada Ochrony Pamięci Walk i Męczeństwa, pełnomocnicy wojewodów do spraw mniejszości narodowych oraz Rzecznik Praw Obywatelskich [Siegień-Matyjewicz 2007: 36; Jagiełło 1997: 15; Wierzycka, Hałuszko 1993; Berdychowska 1995: 3].

W warunkach demokratycznych władze zaczęły zauważać pozytywną rolę mniejszości jako „naturalnego pomostu” w stosunkach Rzeczypospolitej z ich państwami macierzystymi [Chałupczak, Browarek 1998: 293]. W efekcie po 1989 roku można było zaobserwować odradzanie się, narodowych, lokalnych i religijnych identyfikacji. Mniejszości narodowe zwróciły się ku własnym korzeniom, tradycyjnej kulturze, starym obyczajom, ku własnej tożsamości. Zaczęły eksponować swoją narodową, etniczną odmienność, pielęgnować idee, 
tradycje narodowe, rozwijać, upowszechniać dorobek kulturalny, wzbogacać różne dziedziny kultury swego narodu promując dzieła oryginalne, nowe, wyjątkowe na zorganizowanych wystawach, koncertach, przedstawieniach teatralnych, sympozjach, wykładach oraz publikując teksty literackie i naukowe. Zgodnie z intencją Znanieckiego zostały uruchomione twórcze „siły społeczne”, ideały narodowe (ideał zjednoczenia narodowego, ideał postępu społecznego, ideał posłannictwa narodowego i ideał niezależności narodowej) są ujmowane w duchu twórczej ekspansji kultury.

W identyfikacji mniejszościowej i etnicznej społeczeństw ważną rolę zaczęli spełniać liderzy młodego pokolenia, którzy utworzyli nowe struktury organizacyjne. W warunkach demokratycznych powstało [Ustawa 1989] szereg nowych instytucji: m.in. instytucje społeczno - kulturalne, naukowe, gospodarcze, edukacyjne, informacyjne - poprzez, które liderzy przekazują członkom wspólnot wartości narodowe i obyczaje, uczą najmłodsze pokolenie historii, języka macierzystego [Mikołajczyk 1996: 85-87]. Przypominanie kart z historii (w szkole, mediach, instytucjach kulturalnych) w istotnym stopniu wpłynęło na budzenie się poczucia identyfikacji wielu jednostek z ich wspólnotami [Gardocka, Sobczak 2010: 85], a zagwarantowanie prawa do oświaty w języku ojczystym i jego realizacja $\mathrm{w}$ systemie szkolnictwa stanowi jeden $\mathrm{z}$ podstawowych wyznaczników położenia mniejszości narodowych i etnicznych w państwie polskim [Pogorzała 2006: 327]. Prawa oświatowe mniejszości narodowych zostały zagwarantowane ustawowo w art. 13 ustawy o systemie oświaty, stanowiącym: „Szkoła i placówka publiczna umożliwia uczniom podtrzymywanie poczucia tożsamości narodowej, etnicznej, językowej i religijnej, a w szczególności naukę języka oraz własnej historii i kultury" [Ustawa 1991] oraz w rozporządzeniu MEN w sprawie organizacji kształcenia umożliwiającego podtrzymywanie poczucia tożsamości narodowej, etnicznej i językowej uczniów należących do mniejszości narodowych [Rozporządzenie 1992]. Szkolnictwo dla mniejszości narodowych po 1989 roku ma charakter wyłącznie publiczny - w Polsce funkcjonują jedynie trzy niepubliczne szkoły finansowane przez rodziców: prywatna szkoła z nauczaniem języka hebrajskiego w Warszawie, szkoła podstawowa dla Romów w Suwałkach i prywatne przedszkole białoruskie w Białymstoku [Łodziński 1998: 58-59]. Największym problemem szkolnictwa narodowego pozostaje brak podręczników do nauki języka ojczystego. Stanowi to ogromną barierę w podtrzymywaniu przez mniejszości narodowe swojej tożsamości i kontynuowaniu tradycji przodków [Siegień-Matyjewicz 2007: 41-42]. 


\section{Instytucje mniejszości narodowych w III Rzeczypospolitej Polskiej}

W III RP powstały liczne instytucje i organizacje mniejszości narodowych. Najwięcej jest instytucji społeczno - kulturalnych, naukowych, edukacyjnych, informacyjnych. Od 1990 roku aktywnie działa jedyna mniejszościowa partia polityczna - Białoruskie Zjednoczenie Demokratyczne. Mniejszość białoruską aktywizują instytucje i organizacje społeczno-kulturalne: Białoruskie Towarzystwo Historyczne założone w 1992 roku, Białoruskie Stowarzyszenie Literackie „Białowieża”, Białoruskie Zrzeszenie Studentów, Stowarzyszenie Dziennikarzy Białoruskich, Rada Programowa Tygodnika „Niwa” - (tygodnik „Niwa” drukowany w języku białoruskim), Związek Białoruski w Rzeczypospolitej Polskiej, Związek Młodzieży Białoruskiej, Białoruskie Towarzystwo Społeczno-Kulturalne założone 1956 roku. Mniejszość ukraińską reprezentuje Związek Ukraińców w Polsce - założony w 1990 roku oraz Związek Ukrainek, Organizacja Młodzieży Ukraińskiej „Płast”, Związek Ukraińskiej Młodzieży Niezależnej, Związek Ukraińców Podlasia, Ukraińskie Towarzystwo Nauczycielskie w Polsce, Ukraińskie Towarzystwo Lekarskie. Szereg instytucji społeczno-kulturalnych promuje naukę i ukraińską kulturę narodową - m.in.: Rada Programowa Tygodnika „Nasze Słowo”, dwumiesięcznika „Nad Buhom i Narwoju” oraz kwartalnika „Zustriczi”, Ukraiński Dom Ludowy (w Przemyślu), Towarzystwo im. Bohdana Łepskiego w Krakowie, Towarzystwo Jarosławian, Towarzystwo Naukowe im. Biskupa Grzegorza Łakoty, Towarzystwo Miłośników Kultury Materialnej Chełmszczyzny i Podlasia w Holi [Gardocka, Sobczak 2010: 81; por. Berdychowska i in. 1995; Wyznania... 2003; Adamczuk, Łodziński 2009; Chodubski 2009]. Mniejszość litewską aktywizuje Litewskie Towarzystwo Społeczno-Kulturalne założone w 1956 roku, Dom Kultury Litewskiej w Puńsku oraz miesięcznik „Ausra”. W województwie podlaskim funkcjonują szkoły nauczające w języku białoruskim, ukraińskim, litewskim. Na rzecz mniejszości żydowskiej od 1950 roku pracuje Związek Gmin Wyznaniowych Żydowskich i Towarzystwo Społeczno-Kulturalne Żydów w Polsce. Problemy mniejszości żydowskiej w Polsce są omawiane na łamach tygodnika „Fołks Sztyme” i miesiecznika „Jidiłe” [Kurcz 1997]. Kulturę narodu żydowskiego propaguje Państwowy Teatr Żydowski w Warszawie oraz Żydowski Instytut Historyczny. Kulturę innych narodów promują muzea: Muzeum Kultury Łemkowskiej w Zyndranowej, Muzeum Nikifora w Krynicy, muzeum w Tarnowie (znajduje się w nim stała ekspozycja poświęcona Romom) i fundacje: Fundacja św. Włodzimierza Chrzciciela Rusi Kijowskiej w Krakowie, Fundacja Judaica w Krakowie, Ośrodek Informacji o Mniejszościach Narodowych w Gdańsku [Łodziński 1998: 68-69]. 
Instytucje, organizacje mniejszości narodowych utrzymują się głównie z przedmiotowych dotacji państwa przeznaczonych na konkretne akcje (Np. budowa placówek oświatowych, ochrona muzeów i zabytków świadczących o historii i kulturze danych grup, działalność wydawnicza, organizacja festiwali) oraz z własnej działalności gospodarczej [Mikołajczyk 1996: 87]. Regulacją działalności kulturalnej mniejszości narodowych w Polsce zajmuje się Ministerstwo Kultury i Dziedzictwa Narodowego, które rozdziela publiczne środki finansowe przeznaczone na działalność kulturalną. Najbardziej dofinansowane są czasopisma mniejszościowe, które są najskuteczniejszym środkiem kontaktu ze słowem ojczystym i mają znaczny wpływ na podtrzymanie tożsamości narodowej. Najważniejsze czasopisma mniejszości, które pokrywane są całkowicie z budżetu państwa, to: białoruskie „Czasopis” i „Niwa” oraz najpoczytniejsze czasopismo mniejszości prawosławnej, wydawanej od 29 lat - „Przegląd Prawosławny”, a także litewska „Ausra”, ukraińskie „Nad Buhom i Narwoju” i „Nasze Słowo”, łemkowska „Zahroda”, romska „Rom pro drom”, niemieckie „Schlesisches Wochenblatt”, „Masurische Storchenpost” i „Hoffnung”, „Rocznik Tatarów Polskich” oraz słowacki „Żivot”.

Z czasopism naukowych redagowanych przez przedstawicieli mniejszości, finansowanych przez państwo, należy wymienić „Białoruskie Zeszyty Historyczne" [Łodziński 1998: 68]. Niektóre pisma mają sponsorów, takich jak Fundacja Współpracy Polsko-Niemieckiej, Fundacja S. Batorego, Fundacja Rolanda S. Laudera, przedstawicielstwa dyplomatyczne. Po 1989 roku najwięcej wychodziło pism ukraińskich, niemieckich i białoruskich (ponad 10 tytułów), których nakład kształtował się zazwyczaj w granicach 1000-2000 egzemplarzy. Pod koniec lat dziewięćdziesiątych największe nakłady miały: niemiecki tygodnik „Schlesische Wochenblatt” (6000 egz.), niemieckie pismo „Hoffnung” (5000 egz.) i ukraińskie „Nasze Słowo” (4550 egz.). Pozostałe grupy mniejszościowe wydawały po kilka tytułów czasopism o niższym nakładzie - słowacki „Żivot”, żydowskie „Jidiłe”, romski „Dialog-Pheniben”, łemkowska „Besida”, „Biuletyn Ormiańskiego Towarzystwa Kulturalnego" [Siegień-Matyjewicz 2007: 45-46]. W ostatnich latach nakłady poszczególnych pism uległy znacznemu obniżeniu. Może to świadczyć o przyjęciu niewłaściwej koncepcji pisma bądź o postępującej polonizacji środowisk mniejszości narodowych [Siegień-Matyjewicz 2007: 46].

Państwo polskie finansuje również programy o mniejszościach narodowych w mediach publicznych zgodnie z ustawą z 29 grudnia 1992 r. o radiofonii i telewizji stanowi, że „do zadań publicznej radiofonii i telewizji należy w szczególności (...) uwzględnianie potrzeb mniejszości narodowych i grup etnicznych" [Ustawa 1992]. Rozgłośnie narodowe nadają audycje w językach mniejszości w Radiu Białystok audycje radiowe w języku białoruskim, litewskim i ukraińskim; 
w Radiu Katowice magazyn mniejszości niemieckiej po polsku i po niemiecku; w Radiu Opole audycję „Nasz Heimat” po polsku, niemiecku, Śląsku. W ostatnich dwóch dekadach w ośrodkach regionalnych telewizji publicznej nadawane są programy w językach społeczności narodowych i etnicznych. Obecnie Oddział TVP w Białymstoku przygotowuje następujące programy cykliczne - „Sami o sobie” - magazyn mniejszości narodowych: białoruskiej, ukraińskiej, litewskiej, tatarskiej, romskiej, emitowany raz w tygodniu w językach narodowych; „Sąsiedzi” - magazyn mniejszości narodowej białoruskiej; „U źródeł wiary” - magazyn prawosławny. Oddział TVP w Gdańsku przygotowuje: „Rodno Zemia, „Magazyn kaszubski” - program w języku kaszubskim i polskim, „Świat zamieszkały” - magazyn ekumeniczny i „Magazyn kociewski”. Oddział TVP w Katowicach emituje: „Schlesische Wochenschau” - program w języku niemieckim z polską wersją napisów, „Oj ni ma jak Lwów” - program w języku polskim, skierowany do mieszkańców byłych kresów wschodnich, po wojnie przesiedlonych na Śląsk, "Zaolzie” - program skierowany do polskiej mniejszości narodowej zamieszkującej południowe tereny czeskiej części Śląska Cieszyńskiego. Oddział TVP w Krakowie przygotowuje: „U siebie” - program w języku polskim z elementami języków mniejszości ukraińskiej, łemkowskiej, słowackiej, romskiej. Oddział TVP w Lublinie: „Dziedzictwo” - program w języku polskim, „Tabor” - program poruszający problematykę mniejszości religijnych i wyznaniowych zamieszkujących ten region. Oddział TVP w Warszawie wydaje: „Telenowyny” - program w języku ukraińskim i polskim, a Oddział TVP we Wrocławiu: „U siebie” - program poświęcony problematyce mniejszości narodowych [Siegień-Matyjewicz 2007: 46-49]. Instytucje i organizacje narodowe, czasopisma oraz środki masowego przekazu założyły swoje strony internetowe, które mają zadanie: informować, edukować, wychowywać, wpływać na odradzanie się poczucia tożsamości narodowej, przynależności narodowej. Państwo polskie jest instrumentem organizacji mniejszości narodowych i licznych instytucji poprzez które mniejszości przekazują swoim członkom wartości, idee, tradycje narodowe.

Instytucje mniejszości narodowych współpracują z polskimi instytucjami w dziedzinie kultury, sztuki, nauki, edukacji. Organizują spotkania integracyjne, wypoczynek dla dzieci i młodzieży, wspólne koncerty i przedstawienia teatralne, konkursy poezji i prozy, wystawy (np. Związek Młodzieży Białoruskiej - organizuje festiwal „Jesień Bardów”, rajdy piesze „Ściana”, imprezę letnią „Noc Kupały”; Stowarzyszenie AB-BA - organizuje przedstawienia teatralne przygotowywane przez koło teatralne „Zabawa w teatr” oraz imprezę „Festiwal Kultur”; Białoruskie Towarzystwo Społeczno-Kulturalne organizuje Festiwal Muzyki Młodej Białorusi „Basowiszcza”, imprezę rokową „Biaełarusian Underground”, program białoruski w TV i tygodnik „Niwa” organizują Ogólnopolski Konkurs 
Białoruskiej Poezji i Prozy). Prowadzona jest naukowa, historyczna i literacka działalność wydawnicza (pismo „Susterczy”, Almach literacki „Termopile”, Białoruskie Zeszyty Historyczne, Biuletyn IPN, periodyki: „Pamięć i Sprawiedliwość”, książki z serii: Dokumenty, Monografie, Relacje i wspomnienia, Albumy) oraz organizowane sympozja naukowe, wykłady, konferencje (m.in. przez Białoruskie Towarzystwo Historyczne, IPN) oraz inicjonowane są wszelkie formy twórczosci dziennikarskiej, publicystycznej (kolumna w czasopiśmie „Niwa” „Prysutność”). Przygotowywane są programy radiowe i telewizyjne: „Białoruski Wypusk”, „Sami o sobie”, „Tydzień białoruski”, „Pod znakiem Pohoni”, „Panorama Litewska”, „Przegląd ukraiński”. Elementem integrującym mniejszości narodowe są promocje dzieł literackich, naukowych poszczególnych członków i liderów. Ich dzieła stanowią ważny wkład do polskiego dziedzictwa kulturowego. Np. w społeczności białoruskiej zwracają uwagę swą działalnością twórczą pisarz Sokrat Janowicz, malarz Leon Tarasiewicz, w środowisku greckim - literat Nikos Chadzinikolau, piosenkarka Eleni Dzokas (Tzokas), tenor operowy Poulos Raptos, w społeczności tatarskiej - dziennikarz, działacz społeczny Maciej Konopacki, poeta Selim Chazbijewicz, w społeczności ormiańskiej zwraca się uwagę m.in. na twórczość reżysera filmowego Jerzego Kawalerowicza i kompozytora, dyrygenta Krzysztofa Pendereckiego. W każdej zbiorowości mniejszościowej spotyka się nazwiska jednostek zasłużonych dla rozwoju życia duchowego, co znajduje odbicie w ich różnorodnej twórczości [Gardocka, Sobczak 2010: 85]. Ważną instytucją generującą postawy i zachowania członków i przywódców mniejszości narodowych są świątynie różnych wyznań. Wspólnoty zwykle w istotnym stopniu zespalane są przez religie. Duchowni pełnią również zwykle rolę czołowych przywódców życia duchowego poszczególnych wspólnot. Decyduje o tym sfera zwyczajów, obyczajów. W świątyniach odbywają się zwykle chrzty, składa się śluby małżeńskie oraz urządza ceremonie pogrzebowe. Liderzy najczęściej aktywnie uczestniczą w uroczystościach religijnych, a duszpasterze (przywódcy duchowni) w świeckich wydarzeniach społeczno-kulturalnych. Współpraca między liderami struktur organizacyjnych wspólnot oraz duchownymi jest generalnie ważnym ogniwem je konsolidującym [Gardocka, Sobczak 2010: 86]. Mniejszości narodowe mają również swoich przedstawicieli w sejmie i senacie, samorządzie terytorialnym, którzy podejmują współpracę na rzecz lokalnej społeczności [Mikołajczyk 1996: 85].

Współpraca zbliża kultury narodowe, przezwycięża antagonistyczne uprzedzenia narodowe, negatywne stereotypy i postawy, pozwala docenić wartości i dorobek kulturalny oraz kształtować wspólne postawy, wartości, ideały - pokojowego rozwoju narodów. 
Kultura narodowa stanowi czynnik odróżniający dany naród od innych narodów, niemniej każda $\mathrm{z}$ nich potrzebuje stałego dialogu z innymi kulturami, inspiracji do współpracy i poszukiwania dróg współistnienia. Wiedza, umiejętność współdziałania, twórcze, zaangażowane postawy, które wskazywał Znaniecki -także dziś wyznaczają drogę do dialogu z grupami narodowymi i etnicznymi w Polsce, pozwalają uniknąć: uprzedzeń, konfliktów, napięć, przemocy oraz pomagają w komunikacji, wspólnym działaniu, przedsiębiorczości, twórczości. Zespolenie wiedzy, umiejętności i postaw w różnorodne typy kompetencji międzykulturowych staje się dziś koniecznością w relacjach, w komunikacji pomiędzy podmiotami życia społecznego [Znaniecki 2001; Korporowicz 2009].

\section{Polskie instytucje narodowe}

Współczesne społeczeństwo polskie ukształtowało się w efekcie realizacji interesów narodowych różnych grup. Nie miało to wpływu na skład społeczeństwa w wymiarze etnicznym, Polacy pozostają zdecydowaną większością. Jak każdy naród również Polacy są w mniejszym lub większym stopniu, wspólnotą diasporyczną. Najadekwatniej jej istotę wyraził Florian Znaniecki pisząc: naród jest grupą zorganizowaną na zasadzie przodownictwa. Jest to grupa kulturalna, o przynależności do niej rozstrzyga podobieństwo jednostki do wzoru idealnego, opartego na wspólnej kulturze oraz świadome uznane przez innych dążenie tej jednostki do uczestnictwa w tej kulturze. Utrzymanie odrębności i jedności w narodzie jest możliwe dzięki instytucjom przodowników kulturalnych, funkcjonujących głównie za pomocą pisma i druku, jako narzędzi rozpowszechniania i utrwalania wartości narodowych [Znaniecki 1973: 58]. Różnorodne postawy światopoglądowe, które wynikają z pochodzenia etnicznego i wyznawanych religii są istotnym czynnikiem kreowania tożsamości państwa polskiego.

Tożsamość narodowa jest jedną z ważniejszych społecznych identyfikacji. Z badań wynika, że wśród Polaków jest bardzo silne poczucie tożsamości narodowej [Szawiel 1989; Jasińska-Kania, Marody 2002a; Koseła 2002]. Trwałe wartości polskiej tożsamości narodowej - tolerancja religijna, dążenia wolnościowe, doświadczenia społeczeństwa wielonarodowego - kształtowały się wraz ze zmieniającymi się realiami europejskimi. Największy wpływ na kształt polskiej tożsamości narodowej mają nadal wartości, idee, symbole oraz tradycje kulturowe i tragiczne losy narodu. Szczególną rolę w utrwalaniu tożsamości spełnia: wspólnota pamięci narodowej, język polski - wspólnota myślenia i odczuwania, symbole narodowe wpływające na kształt świadomości narodowej: godło, barwy 
narodowe, hymn narodowy oraz literatura, muzyka, sztuka, obyczaje, historia, folklor. Czynnikiem narodotwórczym jest również treść przekazu religijnego, język religii i obyczaj (ryt liturgiczny). Od wieków polska tożsamość narodowa powiązana była $\mathrm{z}$ religijnością chrześcijańską. Utrata niepodległości spowodowała, że tożsamość narodowa była formowana w opozycji do instytucji państwowych i umacniana przez udział w rytuałach religijnych. Po 1989 roku tożsamość religijna i tożsamość narodowa zaczęły się kształtować niezależnie od siebie. W warunkach demokratycznych miłość do ojczyzny, pielęgnowana jest przez instytucje kulturalne, Kościół, szkołę, rodzinę. Powyższe instytucje zgodnie podkreślają, że patriotyzm powinien przejawiać się nie tylko w miłości i geście, ale w całej praktyce życia, w pracy dla wspólnego dobra i w solidnej trosce o naród [Lewandowski 1989: 43]. Przypominają, że ważną rolę wychowawczą pełni postawa: rodziców, nauczycieli, historyków, duchownych, osób publicznych - polityków, dziennikarzy, ludzi prezentujących autorytet ważnych instytucji społecznych. Podmiotem wychowania: patriotycznego, moralnego są nie tylko dzieci i młodzież, ale też ludzie kultury i polityki, media. Celem całościowej formacji duchowej, intelektualnej i kulturalnej realizowanej przez polskie instytucje narodowe, wychowawcze i kulturalne jest pielęgnowanie patriotyzmu w społeczeństwie, a w szczególnosci: budowanie świadomości i więźi narodowej, szacunku dla ojczyzny, barw i symboli narodowych, kultywowanie tradycji i obyczajów oraz poznanie historii ojczyzny, idei narodowych i społecznych, wartości nadrzędnych, jak: wierność tradycyjnym cnotom chrześcijańsko-narodowym, walka o byt narodowy i państwowość polską.

Największe polskie instytucje kultury symbolicznej, Instytut Pamięci Narodowej (IPN), Narodowy Instytut Fryderyka Chopina w Warszawie, Polska Akademia Nauk, Muzeum Historii Polski, Muzea Wojska Polskiego, Muzeum Powstania Warszawskiego, prowadzą działaność kulturalną, naukową, ekonomiczną, edukacyjno-wychowawczą, wydawniczą, archiwistyczną, lustracyjną, wzbogacają kulturę narodową, podnoszą poziom wykształcenia społeczeństwa oraz dążą do zachowania dziedzictwa narodowego i jego wartości, chronią najcenniejsze składniki polskiej tożsamości narodowej - tradycje narodowe, eksponują polskie wartości narodowe - miłość do ojczyzny, honor, pamięć o historii, dumę narodową, odwagę, siłę myśli, jedność i moralność narodu. Daje to społeczeństwu polskiemu większe poczucie godności, jedności i wyższości narodowej względem innych narodów oraz staje się czynnikiem ułatwiającym jego „otwartość”, gotowość do pracy na rzecz dobra wspólnego. Jednocześnie utrwalają w społeczeństwie przeświadczenie, iż Polska powinna być jednak państwem jednolitym etnicznie i kulturowo. 
Narodowy Instytut Fryderyka Chopina w Warszawie buduje pozytywny wizerunk Polski poprzez kultywowanie i ochronę dziedzictwa Fryderyka Chopina - postaci symbolizującej szczytowe osiągnięcia kultury narodowej. Instytut stawia w centrum uwagi kwestie kultury i związane $\mathrm{z}$ nią podstawowe zagadnienia tożsamości, doświadczenia wspólnej tradycji kulturalnej tworzącej więzi międzypokoleniowe. Instytut propaguje wiedzę o Chopinie, promuje twórczość muzyczną, wspiera rozwój utalentowanych młodych muzyków, stymuluje rozwój oryginalnych badań naukowych, rozbudza zainteresowania młodych naukowców problematyką chopinologiczną, tworzy warunki do rozwoju turystyki kulturalnej, organizuje konferencje, koncerty i konkursy pianistyczne (Ogólnopolski konkurs pianistyczny; Konkurs pianistyczny dla dzieci i młodzieży; Międzynarodowy konkurs pianistyczny im. Fryderyka Chopina) ${ }^{1}$.

Instytut Pamięci Narodowej propaguje wiedzę historyczną w społeczeństwie i wartości nadrzędne, jak: wierność tradycyjnym cnotom chrześcijańsko-narodowym, walka o byt narodowy i państwowość polską oraz wskazuje na duchową tożsamość narodu na przestrzeni dziejów [Zwoliński 2005: 155]. Instytut realizuje również zadanie egzekwowania sprawiedliwości wynikające z „obowiązku ścigania zbrodni przeciwko pokojowi, ludzkości i zbrodni wojennych” [Sprawozdanie... 2011], podejmuje starania wynagrodzenia cierpień osobom, które doznały ich w przeszłości ze strony reżimów totalitarnych. IPN szczególnie dba o zachowanie pamięci o ofiarach poniesionych przez Naród Polski w latach II wojny światowej i po jej zakończeniu oraz eksponuje czyny obywateli dokonywane na rzecz niepodległego bytu państwa polskiego i w obronie wolności oraz godności ludzkiej, promuje postawy obywatelskie służące wspólnemu dobru. Instytut Pamięci Narodowej jest instytucją o bardzo szerokich kompetencjach. Prowadzi działalność równolegle w wielu obszarach - realizuje projekty badawcze, edukacyjne, wydawnicze, organizuje konferencje, seminaria, wystawy, wspiera inicjatywy i środowiska kombatanckie w upamiętnianiu najnowszej historii Polski. Zagadnienia podejmowane przez IPN są propagowane przez Internet (multimedialne portale edukacyjne IPN) oraz publikacje edukacyjne, czasopisma naukowe („Pamięć i Sprawiedliwość”, „Aparat Represji w Polsce Ludowej 1944-1989”, „Przegląd Archiwalny IPN” i popularnonaukowy miesięcznik „Biuletyn Instytutu Pamięci Narodowej”), książki historyczne (drukowane i elektroniczne), informatory, katalogi, komiksy historyczne (seria „Wilcze tropy”), edukacyjne gry planszowe (Kolejka, Instytut). IPN organizuje również konkursy historyczne („W kalejdoskopie Pamięci - Polska i Po-

Strona internetowa Narodowego Instytutu Fryderyka Chopina w Warszawie, Aktualności, Edukacja, Płyty, Książki, Koncerty, Konkursy, http://www.pl.chopin.nifc.pl, portal Narodowego Instytutu Fryderyka Chopina w Warszawie [31.07.2013] 
lacy w latach 1939-1989. Autorytet w czasach trudnych”, „Sprzączki i guziki z orzełkiem ze rdzy") i wystawy popularyzujące najnowszą historię Polski (ponad 300 wystaw). Wszystkie ekspozycje są bezpłatnie wypożyczane szkołom oraz placówkom kulturalnym i oświatowym w kraju i za granicą. Wśród instytucji, z którymi współpracuje IPN szczególnie miejsce zajmują placówki muzealne (m.in. z Muzeum Historii Polski, Muzeum Powstania Warszawskiego, Muzeum na Majdanku, Muzeum Stutthof, Muzeum Niepodległości w Warszawie, Muzeum II Wojny Światowej w Gdańsku, Muzeum Śląskim w Katowicach) i oświatowe, w których Instytut prowadzi edukację historyczną młodzieży (wykłady i warsztaty, rajdy, terenowe lekcje historii i konwersatoria dla uczniów, nauczycieli, studentów), [Sprawozdanie... 2013]. W Centrum Edukacyjnym IPN im. Janusza Kurtyki „Przystanek Historia” odbywają się spotkania, dyskusje, prezentacje filmów, wystaw i publikacji dla młodzieży i osób dorosłych.

Obok działalności edukacyjnej, naukowej i wydawniczej (prowadzonej przez Biuro Edukacji Publicznej IPN) Instytut realizuje zadania archiwistyczne, śledcze, lustracyjne. Funkcja lustracyjna IPN od początku budzi wiele kontrowersji oraz sprzeciw niektórych środowisk społecznych.

\section{Przejawy konfliktów, antagonizmów narodowościowych w społeczeństwie}

Z perspektywy mniejszości narodowych działania wielu polskich instytucji, które podkreślają nadrzędność kultury polskiej w stosunku do kultur innych narodów powodują podziały według kryterium: „swoi - obcy”, utrwalają bariery tożsamościowe, nieporozumienia wynikające z odmiennej tożsamości etniczno-kulturowej społeczeństw mniejszościowych. Potwierdzają to m.in. wyniki badań A. J. Siegień-Matyjewicz [2007: 235-258], A. Sadowskiego [1991: 105-110; 1995: 186], G. Babińskiego [1999].

Z badań wynika, że źródłem niechęci wobec mniejszości narodowych jest duże poczucie jedności narodowej Polaków, poczucie wyższości względem innych narodów, a także zawiść, etnocentryzm, brak tolerancji, szacunku wobec innych poglądów, brak znajomości historii, tradycji, obyczajów, obrzędów mniejszości i nie odróżnianie ich od obrzędów oraz obyczajów typu religijnego. Takie zachowania powodują najczęściej poczucie niedowartościowana członków społeczeństw narodowych, a przez to wzbudzają u nich złość, nienawiść i mogą być źródłem konfliktów. Nieprzychylność wobec mniejszości narodowych wynika także, zdaniem respondentów, z trudności życia codziennego 
mieszkańców państwa polskiego oraz z przekonania, że członkowie mniejszości utrudniają Polakom dostęp do pracy, różnych przywilejów (np. władzy, stanowisk, kapitału), [Siegień-Matyjewicz 2007: 244; Babiński 1999: 101]. Badani winą za wszelkie konflikty o charakterze etnicznym obarczają przede wszystkim Polaków, którzy - zdaniem respondentów- dyskryminują mniejszość. Uważają, że podłożem konfliktów na tle etnicznym są różnice typu religijnego, które wiążą się najczęściej z innymi terminami obchodzenia świąt (katolickich i prawosławnych), różnice językowe oraz bieda, bezrobocie i bezdomność. Negatywny stosunek mniejszości do Polaków związany jest ze zjawiskami naznaczania etnicznego przedstawicieli mniejszości narodowych, brakiem regulacji prawnej wielu spraw własnościowych powodujących rozbieżności między interesami większości i mniejszości narodowych (np. spór o prawo do własności poklasztornej w Supraślu, brak zgody na wybudowanie nowej cerkwi prawosławnej w Białymstoku, brak zgody na organizację festiwalu kultury ukraińskiej w Przemyślu, spory dotyczące lokalizacji różnych obiektów - np. pomnik UPA w Przemyślu, niszczenie i przebudowy cerkwi greckokatolickich), niedopuszczaniem społeczeństw mniejszościowych do aktywnego uczestnictwa w życiu politycznym Polski [Siegień-Matyjewicz 2007: 245-250; Babiński 1999: 100-107]. Zdaniem mniejszości Polacy tworzą oddzielne kręgi kulturowe, separują się od mniejszości, są mniej tolerancyjni, starają się narzucić wyższość swojej religii, czują się bardziej u „siebie”, są bardziej otwarci, nie wstydzą się swego pochodzenia, bardziej wiedzą, o co im chodzi w życiu [Sadowski, Tefelski, Mironowicz 1999: 69; Babiński 1999: 97-115; Sołdra-Gwiźdź 1999: 137-140]. Dodatkowo kategorię obcości gruntują mity i stereotypy. Zwykle pod wpływem utrwalonych negatywnych stereotypów o postawach i zachowaniach społeczno-politycznych i ekonomicznych określonych wspólnot, wyraża się do nich stosunek, zarówno w wymiarze akceptacji, jak i dezaprobacie. Stereotypy generowane są zwykle na bazie doświadczenia kontaktów między wspólnotami, a zwłaszcza w sytuacjach napięć, prześladowań [Sadowski, Tefelski, Mironowicz 1999: 65-71]. Negatywnym zjawiskiem w funkcjonowaniu stereotypów jest megalomania, wyrażająca się w lansowaniu swojego uprzywilejowania w dążeniu do podporządkowania innych społeczności, uznawaniu się za tzw. „wspólnoty wybrane”, a też przypisywanie własnej wspólnocie szczególnych uzdolnień, predyspozycji przy jednoczesnym negowaniu wartości i zasług innych [Siegień-Matyjewicz 2007: 244-245]. Polska megalomania sprawia, że mniejszości (przynajmniej niektóre) nie czują się komfortowo w morzu polskości.

W III Rzeczypospolitej megalomania jest zjawiskiem wszechobecnym w życiu publicznym, politycznym. W warunkach demokratycznych społeczeństwa 
narodowe nie były w centrum życia politycznego i zainteresowań ugrupowań politycznych, nie były elementem spójnych koncepcji programowych partii politycznych, stanowiły jedynie sprawę marginalną, która ujawniała się przy określonych wydarzeniach politycznych (np. ratyfikacja traktatu z Niemcami w 1991 roku, dyskusje nad projektem ustawy o mniejszościach), [Wójcik 2001:258-262, 279-280]. Państwo polskie w warunkach demokratycznych okazało się kulturowe w takim sensie, że uznaje obecność mniejszości narodowych, a także oczekiwania większości - prawa do ochrony kultury większości (polskiej). Stąd obok przyjętych ustaw gwarantujących prawa mniejszościom narodowym - Ustawy o mniejszościach narodowych i etnicznych [Ustawa 2005] oraz konstytucyjnej ochrony mniejszości narodowych i etnicznych (art. 55 Konstytucji z 1997 r.) i specjalnych gwarancji ich praw w ustawach dotyczących edukacji, radia i telewizji, ordynacji wyborczej do Sejmu - zostały uchwalone ustawy o repatriacji, ochronie języka polskiego, ochronie polskiego dziedzictwa kulturowego, obywatelstwie polskim i Karcie Polaka [Łodziński 2006: 311]. Wymiarem, który kształtuje politykę państwa wobec mniejszości narodowych, jest ochrona kultury polskiej (praw większości). Powoduje to, że trudniejsze jest wprowadzanie regulacji dotyczących ochrony mniejszości (np. specjalnej ustawy). Sytuacja mniejszości narodowych w ostatnich dekadach zależała nie tylko od ich elit i takich czynników, jak reakcja państwa na ich postulaty, atrakcyjności innych krajów, tempa rozwoju gospodarczego, oceny przebiegu procesu integracji z Unią Europejską [Koseła, Szawiel, Grabowska, Sikorska 2002: 189], ale również od kształtowania się publicznej obecności polskiej tożsamości narodowej.

Dotychczas polska tożsamość narodowa koncentrowała się na utrzymaniu i kontynuacji „polskości”, obecnie wyzwania (integracja europejska i procesy globalizacji) powodują przesuwanie jej ku wymiarowi "granic” między „nami” a „innymi” („obcymi”), [Jasińska-Kania 2002b: 280-288]. Tworzy to nowe i trudniejsze niż dotychczas wyzwania dla polityki państwa wobec mniejszości narodowych. Niewątpliwie jednak najważniejszym wyzwaniem jest kwestia wspierania przez państwo tożsamości narodowej mniejszości, zagwarantowane im praw oraz troska o terytorialną całość kraju i jego bezpieczeństwo. Społeczeństwo polskie musi zaakceptować mniejszości i swoistą ambiwalencję występującą w postulatach mniejszości: z jednej strony domaganie się takich samych praw, jakie posiada większość, z drugiej zaś - podkreślanie swojej inności. Zdaniem M. Jagiełło „konieczne jest zaakceptowanie i praktyczne uznanie tej dwoistości. Skoro członkowie mniejszości narodowych są obywatelami Rzeczypospolitej Polskiej, to przysługują im wszystkie prawa obywatelskie. Skoro część naszych współobywateli jest zanurzona w polskim morzu, to nieodzowne są specjalne uregulowania prawne i specjalna pomoc finansowa państwa w celu podtrzymania ich naro- 
dowej i kulturowej tożsamości. To nie jest uprzywilejowanie mniejszości, to tylko wyrównanie szans, łagodzenie niedogodności bycia wyspą w morzu innego narodu i innej kultury" [Jagiełło 2000: 67; Siegień-Matyjewicz 2007: 50-51]. Społeczeństwa narodowe $\mathrm{z}$ kolei muszą poradzić sobie $\mathrm{z}$ najważniejszym problemem - zagrożeniem asymilacją - stopniowym przyjmowaniem kultury obcej (w tym przypadku większościowej - polskiej) przy jednoczesnej utracie kultury własnej.

Dane statystyczne wskazują, że wszystkie mniejszości narodowe i etniczne w Polsce (z wyjątkiem Romów) gwałtownie się starzeją [Siegień-Matyjewicz 2007: 54], a młode pokolenie coraz rzadziej używa ojczystego języka, ponieważ nie czuje się spadkobiercą narodowej historii i kultury i nie odczuwając etnicznej identyczności odwraca się od swoich korzeni, przyjmuje polski język, obyczaje, kulturę, a dalszej perspektywie utożsamia się z polskością [Czykwin 1995: 406]. Jednocześnie - jak wskazują badania A. Sadowskiego [Sadowski, Tefelski, Mironowicz 1999: 58-64] - wychowanie w wielu rodzinach mniejszości białoruskiej nastawione jest na asymilację, ma za zadanie przygotowanie dzieci do uczestnictwa w kulturze polskiej. Ponadto migracje, emigracje oraz zwiększająca się atrakcyjność kultury masowej w języku polskim dodatkowo ułatwiają asymilację mniejszości. Tendencje do izolacjonizmu i ekskluzywizmu kulturowego wśród mniejszości w Polsce nie są zbyt powszechne [Babiński 1999: 114]. „Topnienie” liczebności grup narodowych i etnicznych przyśpiesza również nierzadko wrogi stosunek polskiej większości względem mniejszości. Ujawniające się antagonizmy, uprzedzenia, postawy separatystyczne powodują wzrost dystansów międzykulturowych, niepewność przyszłego losu i w efekcie coraz mniej młodych ludzi przyznaje się do narodowości lub etniczności przodków [Siegień-Matyjewicz 2007: 54].

Współcześnie w społeczeństwach narodowych, ujawnia się klasyczna dychotomia postaw i zachowań. Pokolenie ludzi „starszych” wykazuje zainteresowanie wartościami tradycyjnymi, zaś pokolenie ludzi młodych orientuje się na wyzwania przyszłości. Odpowiadając na znaki czasu uczestniczy w uniwersalizmie życia kulturalnego, ujawnia duże zainteresowanie zjawiskami globalnymi w życiu kulturalnym, a nie zauważa inicjatyw lokalnych. Obecnie obserwuje się masowe uczestnictwo społeczne w wydarzeniach muzycznych, wystawienniczych, literackich, teatralnych czy kinowych, mających zasięg światowy czy ogólnokrajowy, zaś marginalne jest zainteresowanie wartościami kultury osadzonymi w tradycji [Gardocka, Sobczak 2010: 88]. Zmniejsza się oficjalna identyfikacja licznych przedstawicieli mniejszości narodowych ze strukturami własnej wspólnoty, a ujawnia się opcja na rzecz identyfikacji z ładem globalnej społeczności obywatelskiej. W niektórych mniejszościach narodowych zmniejsza się zainteresowanie posługiwaniem się własnym językiem na rzecz 
komunikacji w języku kraju zamieszkiwania. Ujawniają się też tendencje na rzecz wprowadzania języków mniejszościowych do życia publicznego, m.in. do urzędów (np. język śląski). Coraz częściej pojawiają się nacjonalizmy lokalne (np. na Śląsku), generujące potrzebę uzyskania ustępstw, autonomii, a nawet suwerenności [Chodubski 2006: 77-78]. Wiele grup czuje się niedowartościowanych, nie znajduje dla siebie środków wyrazu w otaczającej je rzeczywistości, co w konsekwencji prowadzi do ujawniania się napięć i konfliktów. Stosunek polskiej większości względem mniejszości ulega polaryzacji. Działania skrajnej prawicy (Młodzież Wszechpolska, Obóz Narodowo-Radykalny, Ruch Narodowy), które coraz częściej są wymierzone przeciwko mniejszościom wręcz kwestionują idee multikulturalizmu.

W społeczeństwie polskim coraz częściej uwidaczniają się podziały dotyczące ważnych kwestii - m.in. stosunku do wspólnego dziedzictwa narodowego, rozumienia patriotyzmu i służby ojczyźnie, a także oceny wydarzeń politycznych, społecznych (obrady „Okrągłego stołu”, „katastrofa smoleńska”, zaangażowanie Polski w niepodległościowe aspiracje Ukrainy, itp.) oraz oceny osób i instytucji (działalność, postawa Lecha Wałęsy, zaangażowanie Kościoła katolickiego w sprawy polityczne).

Wyniki ostatnich wyborów do Sejmu i Parlamentu Europejskiego pokazują istotne, dychotomiczne pęknięcie mentalne Polaków. Zdaniem prof. P. Śpiewaka - komentującego wyniki wyborów do Sejmu w 2011 roku - „Polacy są już trwale podzieleni” [Śpiewak 2011]. Znaniecki podkreślał, że sukces i rozwój narodu - wspólnoty wartości, symboli, ideałów - zależy od twórczych, konstruktywnych postaw i aktywnej działalności przodowników kultury, którzy formułują ideały, programy określające przyszłość, perspektywy, wizje, do których naród powinien dążyć. Jego zdaniem tylko twórcze, czynne współdziałanie przodowników kulturalnych prowadzi do rozwoju społeczeństwa, natomiast agresja, wrogość prowadzą w sposób nieunikniony do antagonizmów i konfliktów z innymi narodami oraz wojen między ich państwami. Dziś szczególnie niepokoją pojawiające się w Polsce bariery tożsamościowe, skrajny indywidualizm, mity i stereotypy w ocenach sąsiadów - eksponowanie tego, co nas dzieli, a nie łączy. Stereotypowe oceny (np. polskości -Prawdziwy Polak czy Polak - katolik) służą głównie skrajnym ugrupowaniom „narodowym”, które wybiórczo traktują tradycje narodowe, osłabiają wartości tożsamości narodowej. Obserwujemy, jak traci na sile deklarowany pozytywny stosunek do wielokulturowości, budowany na bazie polskiej tradycji tolerancji dla „innych” oraz rosnące społeczne przyzwolenie dla idei jednorodności i poparcie dla organizacji narodowych - Młodzież Wszechpolska, Obóz Narodowo-Radykalny oraz nowej inicjatywy społeczno-politycznej: Ruchu Narodowego. Rozwija on 
ogólnopolską sieć organizacji i środowisk nawiązujących do patriotycznych tradycji - m.in. z okresu II Rzeczypospolitej oraz haseł Romana Dmowskiego wzywających naród do walki, współzawodnictwa. Zdaniem R. Dmowskiego „Niepodległość zdobywa ten naród, który nieustannie buduje ją swą pracą i walką. Tę pracę trzeba zacząć od wytępienia chwastów moralnych i umysłowych, zanieczyszczających polską duszę, tę walkę trzeba prowadzić co dzień, na każdej placówce w obronie podstaw, na których budowa przyszłego państwa ma się wznosić" [Dmowski 2007: 19]. Życie wymaga od każdego narodu nowoczesności, zdolności do współzawodnictwa z innymi [Dmowski 2007: 19].

Ruch Narodowy - powołany w 2012 roku - bezkompromisową postawą ideową zmierza do przywrócenia obozowi narodowemu dominującej roli w życiu publicznym. Misją Ruchu Narodowego jest walka o suwerenność kraju, o naprawę polityczną i gospodarczą zawłaszczonego państwa, o obronę wolności jego obywateli i o realizację w sferze kultury i polityki tradycyjnych wartości [Deklaracja... 2013]. Najważniejsze ideały kultury narodowej Ruch Narodowy swobodnie interpretuje, deformuje. Idea zjednoczenia narodowego jest rozumiana przez narodowców jako nakaz zabezpieczania się wobec zagrożeń ze strony innych narodów i ich kultur. Ruch Narodowy postuluje likwidację wszelkich wewnętrznych różnic etnicznych, religijnych, politycznych, demokracji, autonomii i tolerancji, a wobec niebezpieczeństw zewnętrznych - przygotowanie silnej obrony militarnej. Ideą narodu jako kulturowej wspólnoty pokoleń - w ujęciu Ruchu Narodowego - jest walka o Polskę dla Polaków, Polskę dumną, silną, dostatnią i bezpieczną. Naród polski według narodowców jest jedynym prawowitym gospodarzem w swoim państwie [Deklaracja... 2013]. Idea postępu obejmuje dążenia do wyprzedzania innych narodów w kulturze, wzrostu znaczenia narodu polskiego, przewodnictwo, hegemonia w stosunkach międzynarodowych. Idea posłannictwa narodowego pojmowana jest jako predestynacja do odegrania szczególnej roli historycznej wśród narodów świata. Naród polski traktowany jest jako najwyższa wartość, a „interes narodu” uznawany jest za ostateczne kryterium oceny dobra i zła. Idea niezależności narodowej interpretowana jest jako zasada nieulegania wpływom innym narodów i kultur, izolowania się od współpracy, zasłaniania się naruszaniem suwerenności swego państwa narodowego przed przyjęciem i respektowaniem międzynarodowo uznanych i akceptowanych norm (np. praw człowieka, wolności obywatelskich). Ruch Narodowy gwarantuje wolność słowa narodowcom, wolność osoby w ramach wspólnoty [Deklaracja... 2013]. Taka interpretacja, rozumienie najważniejszych ideałów, inspiruje, pobudza kształtowanie się w narodzie „sił społecznych”, które prowadzą do konfliktu z innymi narodami i budowania jednorodnego społeczeństwa. Stanowi to zagrożenie dla stworzonych po 1989 
roku dobrych warunków rozwoju mniejszości narodowych, dialogu, współpracy i partnerskiej wymiany wartości kulturowych. Niewątpliwie może destabilizować życie społeczne w III Rzeczypospolitej Polskiej.

Wspólne korzenie kultury, wspólne ideały i wartości duchowe oraz demokracja, wolność, równość, praworządność, wolny rynek, prawa człowieka tworzą dziś szeroką płaszczyznę współpracy między grupami narodowymi w Polsce. Znaniecki docenił zasadę partnerstwa narodów jako struktur opartych na wolnym uczestnictwie w kulturze. Miał rację, że skierowanie rywalizacji grup narodowych w sferę twórczości kulturalnej, ułatwi współdziałanie i rozwój, pomoże w usunięciu antagonizmów narodowych.

Odradzający się w Polsce nacjonalizm wskazuje, że są potrzebne działania i zmiany, aby nie dopuścić do zbędnych napięć i konfliktów. Kluczem do powodzenia będą: zmiany świadomości społecznej, a przede wszystkim uznanie prawa do współistnienia innych hierarchii aksjologicznych, innych wierzeń i religii. Niewątpliwie w Polsce potrzebne będzie zerwanie z ortodoksyjnie pojmowanym prymatem katolicyzmu, zerwanie z mitem Polaka-katolika. Istotnej modyfikacji wymaga również tradycyjna koncepcja narodu - narodu wybranego. Ponadto skutecznym sposobem zapobiegania konfliktom narodowościowym jest wdrażanie zasad pluralizmu kulturowego poprzez: wprowadzenie w szkole zajęć z edukacji międzykulturowej, kształtowanie postawy otwartości, tolerancji i poszanowania wobec mniejszości (działania wychowawcze prowadzone przez różne instytucje) oraz zagwarantowania należnych jej praw obywatelskich (działania polityczno-prawne), [Siegień-Matyjewicz 2007: 247-248].

\section{Zakończenie}

Przyszłość społeczeństwa polskiego zależy w dużej mierze od pozycji politycznej i ekonomicznej Rzeczypospolitej oraz zakresu wykorzystywania polskiego dorobku kulturowego, który - jak zauważył Znaniecki - może służyć wzbogacaniu świadomości narodowej, stanowić wzór dla patriotycznej postawy oraz eliminowania negatywnych cech narodowych. W III Rzeczypospolitej zostały stworzone warunki do rozwoju kultur narodowych i regionalnych, m.in. przez regulacje prawne. Władze polskie od początku transformacji starały się chronić mniejszości kulturowe zgodnie z obowiązującymi standardami w UE, przygotowały wiele regulacji prawnych zawierających tzw. „dyskryminację pozytywną" - (m.in. obniżenie progu wyborczego w wyborach parlamentarnych, większe subwencje dla szkół mniejszości i obowiązek dyrekcji szkół publicznych orga- 
nizowania lekcji języka ojczystego w przypadku zgłoszenia się trzech uczniów, tworzenie niewielkich jednostek administracyjnych uwzględniających istnienie skupisk narodowościowych, uprzywilejowane finansowanie działalności kulturalnej i wydawniczej, audycje w mediach publicznych w językach mniejszości). W warunkach demokratycznych w III RP narodowe wspólnoty zakorzenione $\mathrm{w}$ różnych kontekstach kulturowych posiadają silne instytucje i organizacje społeczne (odrębne od instytucji państwowych), które upowszechniają treści kulturowe oraz dbają o zachowanie dziedzictwa kulturalnego wspólnoty. „Zasadą odrębności" tych grup jest wspólna swoista kultura.

\section{Bibliografia}

Adamczuk Ł., Łodziński S. (red.), (2006), Mniejszości narodowe w świetle Narodowego Spisu Powszechnego z 2002 roku, Warszawa

Babiński G. (1999), Pogranicze polsko-ukraińskie. Etniczność-zróżnicowanie religijne-tożsamość,

[w:] J. Mucha, Kultura dominujaca jako kultura obca, Warszawa

Berdychowska B. (1995), Wobec mniejszości, „Społeczeństwo Otwarte” nr 4

Berdychowska B. i in. (red.), (1995), Mniejszości narodowe w Polsce, Warszawa

Bołtryk M. (2012), Mniejszości w spisie, „Przegląd Prawosławny” nr 11

Budyta-Budzyńska M. (2010), Socjologia narodów i konfliktów etnicznych, Warszawa

Chałupczak H., Browarem T. (1998), Mniejszości narodowe w Polsce 1918-1995, Lublin

Chodurski A. (2006), Mniejszości narodowe a globalna społeczność obywatelska, [w:] E. Michalik, H. Chałupczak (red.), Mniejszości narodowe i etniczne w procesach transformacji $i$ integracji, Lublin

Chodurski A. (2009), „Obcy - swoi”. Mniejszości narodowe i etniczne na Wybrzeżu Gdańskim, „Echo Pomorza” nr 1

Czykwin J. (1995), Świadomość narodowa Białorusinów polskich w przekazie literackim, [w:] J. Nikitorowicz (red.), Edukacja międzykulturowa. W kręgu potrzeb, oczekiwań i stereotypów, Białystok

Deklaracja ideowa Ruchu Narodowego z dnia 19 stycznia 2013 roku, http://www.ruchnarodowy. org [portal Ruchu Narodowego], [1.09.2013]

Dmowski R. (2007), Myśl nowoczesnego Polaka, Szwecja

Gardocka T., Sobczak J. (red.), (2010), Prawa mniejszości narodowych, Toruń

Jagiełło M. (1997), Dziesięć uwag o mniejszościach narodowych, „Literatura” nr 4

Jagiełło M. (2000), Wspólnota w kulturze, [w:] T. Pilch (red.), O potrzebie dialogu kultur i ludzi, Warszawa

Jasińska-Kania A., Marody M. (2002a), Identyfikacja europejska a tożsamość narodowa Polaków, [w:] A. Jasińska-Kania, M. Marody (red.), Polacy wśród Europejczyków. Wartości społeczeństwa polskiego na tle innych krajów europejskich, Warszawa 
Jasińska-Kania A., Marody M. (2002b), Integracja europejska a tożsamość narodowa Polaków [w:] A. Jasińska-Kania, M. Marody (red.), Polacy wśród Europejczyków. Wartości społeczeństwa polskiego na tle innych krajów europejskich, Warszawa

Kłosowska A. (2005), Kultury narodowe u korzeni, Warszawa

Konstytucja Rzeczypospolitej Polskiej z dnia 2 kwietnia 1997 r. (Dz.U. nr 78 poz. 483)

Korporowicz L. (2009), Komunikacja symboliczna rozwoju tożsamości kulturowej, [w:] D. Wadowski (red.), Tożsamość polska w odmiennych kontekstach, Lublin

Koseła K. (2002), Europejska tożsamość Polaków w teorii i badaniach, [w:] K. Koseła, T. Szawiel, M. Grabowska, M. Sikorska (red.), Tożsamość Polaków a Unia Europejska, Warszawa

Kurcz Z. (1997), Mniejszości narodowe w Polsce, Wrocław

Lewandowski J. (1989), Naród w nauczaniu kardynała Stefana Wyszyńskiego, Warszawa

Łodziński S. (1998), Przekroczyć własny cień. Prawne, instytucjonalne oraz społeczne aspekty polityki państwa polskiego wobec mniejszości narodowych w latach 1989-1997, [w:] B. Berdychowska, (red.), Mniejszości narodowe w Polsce. Praktyka po 1989 roku, Warszawa

Łodziński S. (2006), Spory wokół ustawy o ochronie mniejszości narodowych etnicznych w Polsce okresu transformacji, [w:] E. Michalik, H. Chałupczak (red.), Mniejszości narodowe i etniczne w procesie transformacji oraz integracji, Lublin

Łodziński S. (1996), Standardy międzynarodowe ochrony praw osób należących do mniejszości narodowych i etnicznych (ONZ, KBWE, Rada Europy) a polski system prawny, Warszawa

Michalik E., Chałupczak H. (red.), (2006), Mniejszości narodowe i etniczne w procesie transformacji $i$ integracji, Lublin

Mikołajczyk B. (1996), Mniejszości w prawie międzynarodowym, Katowice

Narodowy Spis Powszechny Ludności i Mieszkań 2002, (2011), GUS, Warszawa

Pogorzała E. (2006), Szkolnictwo mniejszości narodowych i etnicznych w Polsce w okresie transformacji, [w:] E. Michalik, H. Chałupczak (red.), Mniejszości narodowe i etniczne w procesie transformacji oraz integracji, Lublin

Rozporządzenie MEN z dnia 24 marca 1992 r. w sprawie organizacji kształcenia umożliwiającego poczucie tożsamości narodowej, etnicznej i językowej uczniów należących do mniejszości narodowych (Dz.U. nr 34, poz. 150)

Sadowski A. (1991), Społeczne problemy wschodniego pogranicza, Białystok

Sadowski A. (1995), Pogranicze polsko-białoruskie. Tożsamość mieszkańców, Białystok

Sadowski A., Tefelski M., Mironowicz E. (1999), Polacy i kultura polska z perspektywy mniejszości białoruskiej, [w:] J. Mucha (red.), Kultura dominujaca jako kultura obca, Warszawa

Siegień- Matyjewicz A. J. (2007), Poczucie tożsamości narodowej młodzieży pochodzenia białoruskiego, Olsztyn-Warszawa

Sołdra-Gwiźdź T. (1999), Problem dominacji kulturowej w społecznościach Ślaska Opolskiego, [w:] J. Mucha, (red.), Kultura dominujaca jako kultura obca, Oficyna Naukowa, Warszawa Śpiewak P. (2011), Wywiad w „Po południu Radia TOK FM”

Szacki J. (1990), Wstęp, [w:] F. Znaniecki, Współczesne narody, Warszawa

Szawiel T. (1989), Grupy społecznej identyfikacji, [w:] S. Nowak (red.), Ciągłość i zmiana tradycji kulturowej, Warszawa

Sztompka P. (2007), Socjologia. Analiza społeczeństwa, Warszawa

Tożsamość narodowa Polaków oraz postrzeganie mniejszości narodowych i etnicznych w Polsce, (2005), Komunikat z badań CBOS 2005 - BS/84/2005. 
Turowski J. (1999), Floriana Znanieckiego koncepcja przezwyciężenia antagonizmów i konfliktów między narodami, [w:] E. Hałas (red.), Teoria socjologiczna Floriana Znanieckiego a wyzwania XXI wieku, Lublin

Ustawa z dnia 6 stycznia 2005 r. o mniejszościach narodowych i etnicznych oraz o języku regionalnym (Dz.U. nr 17, poz. 141)

Ustawa z dnia 7 kwietnia 1989 r. Prawo o stowarzyszeniach (Dz. U. nr 20, poz. 104)

Ustawa z dnia 7 września 1991 r. o systemie oświaty (t.j. Dz.U. 1996 nr 67, poz.329 z późn. zm.)

Ustawa z dnia 29 grudnia 1992 r. o radiofonii i telewizji (Dz.U. $1993 \mathrm{nr}$ 7, poz. 34)

Wierzyca Ł., Hałuszko M. (1993), Uwagi o mniejszościach narodowych w Polsce. Osiagnięcia i porażki w ochronie ich praw, „Społeczeństwo Otwarte” nr 9

Wójcik A. (2001), Mniejszości narodowe we współczesnej polskiej myśli politycznej, [w:] J. Jachymek, W. Paruch (red.), Między rzeczywistością polityczną a światem iluzji. Rozwiązania problemu mniejszości narodowych w polskiej myśli politycznej XX wieku, Lublin

Wyniki Narodowego Spisu Powszechnego Ludności i Mieszkań 2011. Podstawowe informacje o sytuacji demograficzno-społecznej ludności Polski i zasobów mieszkaniowych, (2011), GUS, Warszawa

Wyznania religijne, stowarzyszenia narodowościowe i etniczne w Polsce 2000-2002, (2003), Warszawa

Znaniecki F. (1973), Socjologia wychowania. Społeczeństwo wychowujące, t. 1, Warszawa

Znaniecki F. (1990), Współczesne narody, Z. Dolczewski (tłum.), Warszawa

Znaniecki F. (2001), Ludzie teraźniejsi a cywilizacja przyszłości, Warszawa

Zwoliński A. (2005), Wprowadzenie do rozważań o narodzie, Kraków

\section{Źródła internetowe}

Sprawozdanie z działalności IPN za 2011 rok, http://www.ipn.gov.pl portal Instytutu Pamięci Narodowej [30.05.2013]

Strona internetowa IPN, Aktualności, Informacja o działalności IPN, http://www.ipn.gov.pl portal Instytutu Pamięci Narodowej [30.05.2013]

Strona internetowa Narodowego Instytutu Fryderyka Chopina w Warszawie, Aktualności, Edukacja, Płyty, Ksiązki, Koncerty, Konkursy, http://www.pl.chopin.nifc.pl, portal Narodowego Instytutu Fryderyka Chopina w Warszawie [31.07.2013] 


\section{SUMMARY}

\section{The Ideas of Nation-Society of Florian Znaniecki under Democratic Conditions on the Example of the Third Republic of Poland}

Florian Znaniecki - a representative of humanistic sociology - claims in his works that a nation is a product of civilization, a cultural group, organized on the principle of leadership. As a spiritual community it can exist independently of the territory and state organization, it is historically variable, its existence is determined by culture that encompasses the entire work of a nation, all material-technical, intellectual, artistic and aesthetic products as well as a language and other symbols as means of communication, all patterns of behaviour and actions, values and ideals (freedom, justice, honor) and standards arising from them. National culture, customs, religious worship, beliefs and ideals of national historical tradition are shared values and national groups are potentially available to all members of the group. "The principle of separateness" of a nation as a cultural group is shared culture.

In democratic conditions of the Third Republic of Poland circumstances for the functioning and development of various types of societies based on the criteria of identity were created. In accordance with F. Znaniecki's intention, national and ethnic groups can develop national culture or pursue shared cultural ideals. The article is an attempt to answer the question: To what extent are the ideas of F. Znaniecki's national society implemented in the Third Republic of Poland? Referring to the literature, the author presents the ideas of F. Znaniecki's national society, selected institutions and national organizations operating in the Third Republic of Poland.

\section{Keywords:}

people, society, the ideas of national society, national culture, cultural group, national identity. 